\title{
Induction of High Affinity Epidermal Growth Factor Binding in the Aorta of Dahl Hypertensive Rats Fed with High Salt Diet
}

\author{
Narayan Swaminathan, and Mohinder P. Sambhi
}

\begin{abstract}
Dahl salt sensitive rats (DS) developed severe hypertension on four weeks of high salt feeding while the Dahl salt resistant rats (DR) remained normotensive under the same conditions. The specific maximal binding of epidermal growth factor (EGF) in the freshly prepared kidney membranes of high salt fed DS rats was higher than those from $D R$ rats $(5.3 \pm 1.9 \mathrm{vs} .1 .6 \pm 0.62 \mathrm{fmoles} / \mathrm{mg}$ protein, $p<0.001)$. Scatchard analysis of EGF binding in the kidney showed one class of receptors in the $D R\left(K_{d}=0.75 \pm 0.05\right.$ $\mathrm{nM})$ as well as in the DS rats $\left(K_{d}=0.69 \pm 0.06 \mathrm{nM}\right)$. The EGF binding in the aortic membranes of DS rats was also high compared to DR rats $(24.98 \pm 5.52 \mathrm{vs}$. $13.20 \pm 4.10$ fmoles $/ \mathrm{mg}$ protein, $p<0.001)$. Scatchard analysis of EGF binding in the aorta showed one class of receptors in the DR aorta with a $K_{d}$ of $0.70 \pm 0.06 \mathrm{nM}$. On the other hand, in the DS rat aorta two classes of receptors, a high affinity form $\left(K_{d}=0.05 \pm 0.01 \mathrm{nM}\right)$ and a low affinity form $\left(K_{d}=3.5 \pm 0.3 \mathrm{nM}\right)$ were noted. The induction of a high affinity species of EGF receptors in the aorta, appears to be a mechanism unique to the salt fed DS rats. (Hypertens Res 1996; 19: 65-68)
\end{abstract}

Key Words: Dahl rats, salt sensitivity, EGF receptor, vascular proliferative response

The development of hypertension in the Dahl saltsensitive rat, when exposed to a diet of high $\mathrm{NaCl}$ content, is dependent on a combination of genetic and environmental factors. The Dahl salt-sensitive (DS) rat is genetically predisposed to become hypertensive, whereas Dahl salt-resistant (DR) rat, remains normotensive (1). The hypertension that develops in the DS rat is severe and is uniformly fatal if salt feeding is continued. Since the reninangiotensin system is suppressed in this model of hypertension (1), several other mechanisms for the development of hypertension have been proposed including an impairment in the ability of the kidneys to handle salt load (2), alterations in immunological $(3)$ or hormonal $(4,5)$ controls, or changes in peripheral noradrenergic function $(6,7)$.

We have previously reported that high salt feeding in the DS rats leads to an increased maximal epidermal growth factor (EGF) binding, in the aortic and kidney tissue membranes (8). In the same study, we had also examined changes in the mRNA expression of growth factors in several tissues. In the kidney tissue, the mRNA expression of EGF receptor (EGFR) was enhanced.

In the aortic tissue, however, no change in the mRNA expression of EGFR was found. Therefore the increased EGF binding observed in the aorta was attributed to a post-translational activation of the EGFR protein. In order to explore the potential mechanisms of the post-translational activation, we have studied the kinetics of EGF binding in the aortic tissue of DR and DS rats following high salt feeding.

\section{Methods}

Dahl salt sensitive (DS) and salt resistant (DR) male rats of 7 weeks of age were obtained from HSD, Inc. The animals were fed for four weeks, with a high salt diet $(8 \% \mathrm{NaCl})$ and were allowed to drink water ad libitum. Systolic blood pressures of the rats were determined by the tail cuff method. During the course of this study five out of $20 \mathrm{DS}$ rats died of the well known effects of high salt feeding in this species (1). These animals were discarded and their tissues were not used for analysis. Chemicals were purchased from: $\mathrm{Na}{ }^{125} \mathrm{I}$ (ICN); mouse EGF (Sigma); rat EGF (Bioproducts) and protein reagent (BioRad). Rat ${ }^{125}$ I EGF was prepared by the chloramine- $\mathrm{T}$ method as described by Carpenter (9).

\section{Isolation of Membranes}

The tissues were sliced into small pieces and homogenized with 4 volumes of $50 \mathrm{mM}$ Tris- $\mathrm{HCl}$ buffer, pH 7.4 containing $0.1 \mathrm{mM}$ PMSF for 30

From the Division of Hypertension, Department of Medicine Veterans Administration Medical Center \& UCLA School of Medicine, CA, USA.

Address for Reprints: Mohinder Sambhi, MD, PhD, Professor Emeritus, Department of Medicine UCLA, 5521 Paradise Valley Road, Hidden Hills, CA 91302-2437, USA.

Received December 12, 1994; accepted in revised form January 17, 1996. 
seconds in a Polytron homogenizer at $0^{\circ} \mathrm{C}$. The homogenate was spun at $1,000 \times g$ for $5 \mathrm{~min}$ and the pellet discarded. The supernatant was spun at $15,000 \times g$ for $20 \mathrm{~min}$ and the pellet was suspended in the homogenizing buffer. This suspension was used as a source of membranes for the binding studies.

\section{EGF Binding Studies}

The binding of ${ }^{125}$ I labelled EGF to the tissue membranes was studied using a reaction mixture in a total volume of $200 \mu \mathrm{l}$ containing $50 \mu \mathrm{l}$ of membrane fraction $(50 \mu \mathrm{g}$ protein), $50 \mu \mathrm{l}$ of Tris- $\mathrm{HCl}$ buffer, $\mathrm{pH} 7.4$ with $1 \%$ bovine serum albumin and about $200,000 \mathrm{cpm}$ of ${ }^{125}$ I labelled EGF at a final concentration of $5 \mathrm{nM}$. After incubation at room temperature $\left(25^{\circ} \mathrm{C}\right)$ for 2 hours, $1 \mathrm{ml}$ of $10.4 \%$ PEG-8000 was added and centrifuged at $1,500 \times g$ for $10 \mathrm{~min}$ in a Sorvall HS-4 rotor. The supernatant was aspirated off and the pellet washed once with $1 \mathrm{ml}$ PEG-8000 and then counted in a gamma counter. The non specific binding was measured in the presence of a large excess of unlabelled EGF and the values were subtracted from the total binding to derive specific binding. Initial studies established that the specific binding was linear from 10 to $150 \mu \mathrm{g}$ membrane protein and that there was no degradation of EGF during the assay period.

\section{Protein Estimation}

The protein content of the membranes was determined according to the method of Lowry et al. (10).

\section{Data Analysis}

The competition binding curves were transformed to Scatchard plots and affinity $\left(K_{\mathrm{d}}\right)$ and maximal binding $\left(B_{\max }\right)$ were determined with the aid of LIGAND analysis (11). Statistical significance between the high and low affinity groups was first established by one way analysis of variance (ANOVA). Student's $t$-test (two-tailed evaluation) was used to compare differences between groups and compute significance. A $p$-value of 0.05 or less was considered significant.

\section{Result}

High salt feeding increased the blood pressure of DS rats. DS rats developed severe hypertension in four weeks of high salt feeding while DR rats remained normotensive (systolic BP, $201 \pm 4$ vs. 138 \pm $4 \mathrm{~mm}$ of $\mathrm{Hg}, n=6, p<0.001$ ). The body weight of either group was not affected significantly $(248 \pm 37$ vs. $288 \pm 19 \mathrm{~g}, n=6$, NS).

Maximal specific EGF binding in the membranes from aorta, heart and kidney of DS and DR rats fed with normal and high salt diets is shown in Table 1 . The binding is higher in DS rat aorta than in DR rat aorta. The kidney from DS rats fed with high salt also showed increased EGF binding. No significant change in EGF binding was noted either in DS or and DR rats in the heart tissue, following high salt feeding.

The effect of increasing EGF concentration on
Table 1. EGF Binding in High Salt Fed Dahl Rat Tissues

\begin{tabular}{lllc}
\hline Strain & Tissue & $n$ & $\begin{array}{c}\text { EGF bound } \\
\text { (fmoles/mg protein) }\end{array}$ \\
\hline DR & Kidney & 5 & $1.60 \pm 0.62$ \\
DS & Kidney & 6 & $5.30 \pm 1.90^{*}$ \\
DR & Aorta & 5 & $13.20 \pm 4.10$ \\
DS & Aorta & 6 & $24.98 \pm 5.52^{*}$ \\
DR & Heart & 6 & $0.83 \pm 0.13$ \\
DS & Heart & 6 & $0.71 \pm 0.09$ \\
\hline
\end{tabular}

Renal, aortic and cardiac tissue membranes from DS and DR rats fed with a high salt diet were analyzed for specific EGF binding. Values shown are mean \pm standard deviation. ${ }^{*} p<0.01$.

EGF binding in aortic membranes is shown in Fig. 1A. The binding in DR increased exponentially with increasing concentration of EGF and saturated around $5 \mathrm{nM}$. This pattern of the saturation binding curve is consistent with a single class of receptors in DR aorta. This conclusion is supported and confirmed by the Scatchard analysis shown in Fig. 1B, wherein the plot of the binding is linear. $\left(K_{\mathrm{d}}=0.7 \pm\right.$ $0.06 \mathrm{nM})$. In contrast the binding pattern in DS rats shown in Fig. 1A has several different noteworthy characteristics. Increased EGF binding can be observed at all added concentration of the agonist. This circumstance could result from an overall increased binding affinity of the receptors, in which case, the binding curve in DS should be approximately parallel and similar in shape to that of DR. On the other hand, the binding curve in DS shown in $1 \mathrm{~A}$ is not smooth and has the appearance of two different components. Scatchard analysis (Fig. 1B) of aortic binding in DS shows two different classes of receptors exhibiting high and low affinity binding. The $K_{\mathrm{d}}$ of the high and low affinity receptors was $0.05 \pm 0.01 \mathrm{nM}$ and $3.5 \pm 0.3 \mathrm{nM}$ respectively, with a difference in affinity of almost two orders of magnitude. Scatchard analysis of the EGF binding data in the DR $\left(K_{\mathrm{d}}=0.75 \pm 0.05 \mathrm{nM}\right)$ or DS $\left(K_{\mathrm{d}}=0.69 \pm\right.$ $0.06 \mathrm{nM}$ ) kidney showed only one class of receptors (Fig. 2).

\section{Discussion}

Appearance of a new species of EGF receptors with high affinity in the salt fed Dahl rat aortae is very interesting. This can not be attributed to physical effects of salt feeding alone, since both DS and DR rats were exposed to high salt under the same conditions. The appearance of high affinity receptors only in DS rats suggests that the putative genetic abnormality in the DS rats being activated on exposure to high salt and resulting in the development of hypertension may somehow be related to the genesis of high affinity receptors. Previous studies, however, using spontaneously hypertensive rats (12) and showing increased binding in the aortic tissue have established that lowering of blood pressure of hypertensive animals by hydralazine treatment does 
(A)

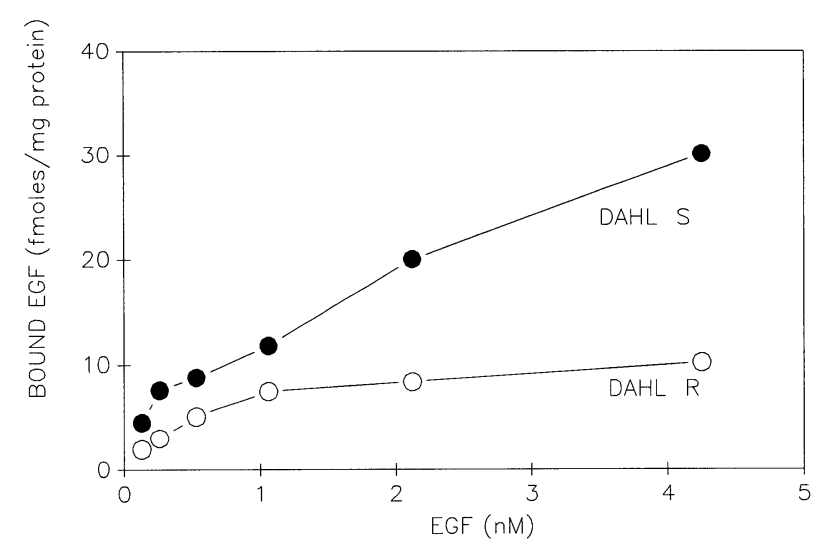

(B)

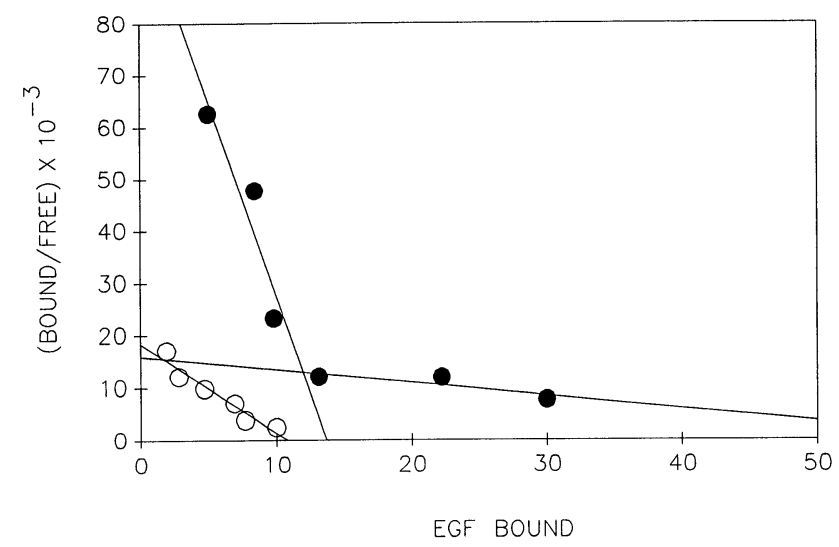

Fig. 1. EGF binding by Dahl rat aortic membranes. (A) EGF binding at increasing EGF concentration. The EGF concentration was varied from 0.1 to $5.0 \mathrm{nM}$. The specific binding (total binding minus the binding in the presence of an excess of unlabelled EGF) is shown. (DS, closed circles; DR, open circles). (B) Scatchard plot of the binding. The aortic membranes from the DR rats exhibit only one type of receptors and the membranes from the DS rat aorta exhibit two types of receptors.
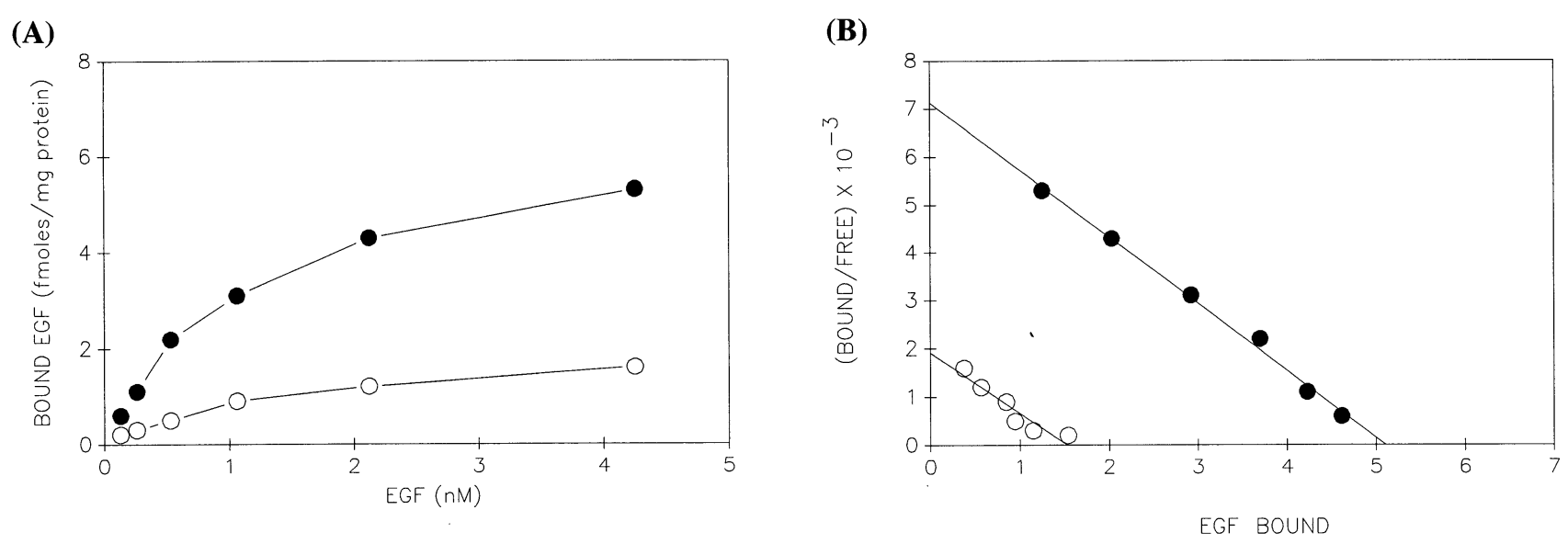

Fig. 2. EGF binding by Dahl rat kidney membranes. (A) EGF binding at increasing EGF concentration. The EGF concentration was varied from 0.1 to $5.0 \mathrm{nM}$. The specific binding (total binding minus the binding in the presence of an excess of unlabelled EGF) is shown. (DS, closed circles; DR, open circles). (B) Scatchard plot of the binding. The kidney membranes from the $D S$ or DR rats exhibit only one type of receptors.

not decrease the EGF binding, implying that the increased blood pressure is not a cause of increased EGF binding.

Furthermore the increased EGF binding in the SHR aortic tissue is observed in young rats before the onset of hypertension is clearly established (8).

The pattern of increased EGF binding in the aortic and renal tissues of DS rats, and the lack of change in the cardiac tissue (Table 1) is consistent with our previous observations in other models of genetic hypertension, using SHR $(13,14)$ and Lyon hypertensive rats (15). It is the aortic tissue however, that in our previous studies exhibited an important difference. In the SHR aorta, increased EGF binding was found to accompany increased mRNA expression of EGFR (13). In the DS rat on the other hand (8), the mRNA levels of EGFR were normal. Furthermore, the binding studies on the aortae from SHR and Lyon hypertensive rats (13, 15) consistently showed only a linear scatchard plot indicating the existence of a single class of EGF receptors. Accordingly we suggest that the appearance of the new species of EGFR receptor with the high affinity in DS rats presumably results from a post translational event, rather than the transcription and synthesis of two different structural forms of the receptor. The present studies, however, do not establish the precise mechanism for the appearance of the high affinity receptors. There is abundant evidence that increased activity of EGFR can result from physical changes such as ligand induced oligomerization (16-19). Also subtle changes in the carbohydrate moiety of the receptors are known to induce significant alterations in its activity (20).

The present observations lend further support to the conclusion of our previous studies in other 
genetic models of hypertension $(12,15)$ suggesting that a strong correlation exists between the development of hypertension and increased EGFR activity in the renal and vascular tissues. This association becomes all the more significant and intriguing with the recognition that the enhanced EGF receptor activity in the vascular tissue can come about in hypertensive models, not only through post transcriptional events resulting in increased mRNA expression and elevated receptor levels such as observed in the SHR as well as in the animals with angiotensin induced experimental hypertension (21), but presumably also as shown in the present study, potentially through post translational events. The mechanisms of an interaction between the appearance of vascular high affinity EGF receptors accompanied with increased EGFR activity in the kidney tissue and salt sensitivity in salt loaded Dahl rats, is a subject for future studies. The present results can support a postulate that such a relationship exists.

\section{References}

1. Rapp JP, Dene H: Development and characteristics of inbred strains of Dahl salt-sensitive and salt-resistant rats. Hypertension 1985; 7: 340-349.

2. Dahl LK, Knudsen KD, Iwai J: Humoral transmission of hypertension: evidence from parabiosis. Circ Res 1969; Vol XXIV and XXV I: 121-133.

3. Cowen LA, Harold MR, Chen C, Abbot RE, Schachter D: Immunoglobulin and renal abnormalities in Dahl genetically hypertensive rat. Am J Physiol 1991; 261: H1895-H1902.

4. Iwai J, Knud D, Knudsen KD, Dahl LK, Tassinari L: Effect of adrenalectomy on blood pressure in salt fed, hypertension prone rats, failure of hypertension to develop in absence of evidence of adrenal cortical tissue. J Exp Med 1969; 663-678.

5. Rowland NE, Fregly MJ: Role of gonadal hormones in hypertension in the Dahl salt sensitive rat. Clin Exp Hypertens 1992; A14: 367-375.

6. Kuchel O, Racz K, Debinski W, Falardeau P, Buu NT: Contrasting dopaminergic patterns in two forms of genetic hypertension. Clin Exp Hypertens Part A Theory Pract 1987; 9: 987-1008.

7. McCaughran JA, Murphy D, Schechter N, Friedman $\mathrm{R}$ : Participation of the central cholinergic system in blood pressure regulation in the Dahl rat model of essential hypertension. J Cardiovasc Pharmacol 1983; 5: 1005-1009.

8. Sambhi MP, Swaminathan N, Wang H, Rong HM: Upregulation of adrenal, renal and vascular growth factors in salt fed hypertensive Dahl rats, in Sassard J (ed): Proceedings of 7 th International Symposium on SHR and related studies. London, Libbey Eurotext Ltd, 1992, pp215-217.

9. Carpenter G: Binding assays for epidermal growth factor. Methods Enzymol 1985; 109: 101-110.

10. Lowry $\mathrm{OH}$, Rosebrough $\mathrm{N}$, Farr AL, Randall RJ: Protein measurement with the Folin phenol reagent. J Biol Chem 1951; 193: 265-275.

11. Munson PJ, Rodbard D: LIGAND: Versatile computerized approach for characterization of ligandbinding systems. Anal Biochem 1980; 107: 220-239.

12. Swaminathan N, Sambhi MP: Increased epidermal growth factor binding by the kidney and aorta of spontaneously hypertensive rats. Hypertens Res 1992; 15: 93-98.

13. Swaminathan N, Sambhi MP: Enhanced activity of epidermal growth factor receptor in the adult SHR aorta. Circulation (Suppl II) 84(4): 2227.

14. Swaminathan N, Vincent M, Sassard J, Sambhi MP: Increased epidermal growth factor receptor levels in the adult SHR kidney. FASEB J 1991; 5(4): A662.

15. Swaminathan N, Sambhi MP: Elevated epidermal growth factor receptor levels in Lyon rat kidney and aorta. Clin Exp Pharmacol Physiol 1995 (in press).

16. Zidovetzki R, Yarden Y, Schlessinger J, Jovin TM: Rotational diffusion of epidermal growth factor complexed to cell surface receptors reflects rapid microaggregation and endocytosis of occupied receptors. Proc Natl Acad Sci 1981; 78: 6981-6985.

17. Fanger BO, Austin KS, Earp HS, Cidlowski JA: Cross-linking of epidermal growth factor receptor in intact cells: Detection of initial stages of receptor clustering and determination of molecular weight of high affinity receptors. Biochemistry 1986; 25: 6414-6420.

18. Cochet C, Kashles O, Chambaz EM, Borello I, King $\mathrm{CR}$, Schlessinger J: Demonstration of epidermal growth factor induced receptor dimerization in living cells using a chemical covalent cross-linking agent. $J$ Biol Chem 1988; 263: 3290-3295.

19. Northwood IC, Davis RJ: Activation of epidermal growth factor receptor tyrosine protein kinase in the absence of receptor oligomerization. J Biol Chem 1988; 263: 7450-7453.

20. Soderquist AM, Carpenter G: Glycosylation of epidermal growth factor in A431 cells: contribution of carbohydrate to receptor function. $J$ Biol Chem 1984; 259: 12586-12594.

21. Sambhi MP, Swaminathan N, Wang H, Rong H: Increased EGF binding and EGFR mRNA expression in rat aorta with chronic administration of Angiotensin II. Biochem Med Metab Biol 1992; 48: 8-18. 